\title{
The Influence of Empowerment of Human Resources, Good Governance, Monitoring and Evaluation of the Quality of Employee Services in Public Hospital of Fatimah Embung Area in Batam City
}

\author{
Rizki Eka Putra ${ }^{1, *}$, R. Madhakomala ${ }^{2}$, Hamidah $^{2}$ \\ ${ }^{1}$ Student of Postgraduate Universitas Negeri Jakarta (UNJ) Indonesia \\ ${ }^{2}$ Universitas Negeri Jakarta (UNJ) Indonesia \\ *Corresponding author.Email: rizkiekaputra@gmail.com
}

\begin{abstract}
This research is aimed at determining the influence of empowering human resources, good governance, monitoring and evaluation, and service quality of the employees. This research applied a quantitative approach with survey method. A path analysis was used to analyze the collected data. The population that was analyzed in this research was all employees who taught at Public Hospital of Embung Fatimah Batam City which was 602 people. An affordable population is an employee of Group III level of 189 people. Random sampling was conducted and selected impartially for a number of 129 people. The result of the research showed that the employee was directly affected by the empowering human resources, good governance and monitoring and evaluation of the employees. This research also discovered that the employees monitoring and evaluation was influenced by the empowering human resources and good governance. This research also discovered that the employee's good governance was influenced by the empowering human resources. Based on those findings, it can be concluded that all changes occur on the service quality of the employees were influenced by the empowering human resources, good governance, and monitoring and evaluation. This service quality, good governance and monitoring and evaluation of the employees can be considered in the strategic planning of human resources development in public organization.
\end{abstract}

Keywords: Service Quality, Empowering Human Resources, Good Governance, Monitoring and Evaluation

\section{INTRODUCTION}

Every organization or company always has the vision to be able to achieve this vision. It needs a mission that must be carried out effectively. Therefore, it requires productivity that is essential in every organization, both in public and private organizations, organizations. Employee productivity can be increased through various ways, including through the empowerment of human resources, where the empowerment of human resources is intended to provide opportunities, capabilities, and protection to employees in carrying out their duties and responsibilities. Thus, it can be said that the empowerment of human resources is an effort that must be carried out by the organization in order to achieve qualified employees so that they have the Ability to utilize, develop, and master science and technology.
As we know, hospitals are health care institutions that are part of the public health service system. Hospitals are part of the most complex organization with very diverse, labour-intensive, capital intensive and high technology. On the other hand, hospitals are required to provide health services to the community with appropriate technology. To deal with these challenges, hospitals must be managed professionally. Therefore, hospital management must pay attention to the quality of adequate service delivery and always consider aspects of effectiveness and efficiency.

A hospital is one of the important health service networks, loaded with tasks, burdens, problems, and expectations that depend on the hospital. The development of the number of hospitals in Indonesia, followed by the development of disease patterns, the development of medical technology, and health and the 
development of community expectations for hospital services make it necessary for reliable managers [1].

Health care is a rapidly growing sector which has gained much attention from researchers and practitioners worldwide. Due to tremendously increasing cost, many hospitals attempt to adopt quality initiatives such as lean and/or Six Sigma to improve their service operations. Implementing such process improvement efficiently and effectively would ultimately help in delivering the highest value to customers. In a globally competitive world, hospitals that can successfully implement an appropriate business process improvement tend to gain a significant competitive advantage [18].

Embung Fatimah Hospital departed from an Outpatient Health Center which was operated on October 8, 1986, called the Batu Aji Health Center. In 1988 his status changed to Inpatient Health Center with six beds. Batu Aji Health Center is gradually evolving as the variety of services offered and in accordance with the medical disciplines of the Batu Aji Health Center, so that the Batu Aji Health Center changed its status to the Class D Public Hospital of Batu Aji, Batam City Government based on Minister of Health Decree RI No. 799/ Minister of Health /SK/VII/2004 and approved by the Mayor of Batam on October 11, 2004.

The need for the existence of Batam City Embung Fatimah Hospital that can carry out its duties and functions in accordance with the hospital functions described above deserves to be fulfilled and it is time for the Batam community to get maximum health services. Therefore, to achieve it, Batam City Embung Fatimah Hospital in Batam City needs to work hard, abstinence, requires physical, mental, and noble personality energy in order to produce a performance that is in line with the goals of the organization, both the leadership, management and employees of the Batam City Embung Fatimah Hospital and the administrative ranks need to be encouraged and encouraged so that the goal reaches the maximum.

There is a bureaucratic problem facing all regional governments in connection with the implementation of good governance in the regional government, both in terms of structure and culture and program nomenclature that supports it. Until now the application of the principles of good governance in local governments is still slogan.

Even the current conditions also show that there are still practices and behaviors that are in conflict with the rules of good governance, which can hamper the implementation of reforms in the central government or regional governments. The implementation of good governance is the basis for the creation and application of democratic state policies in the era of globalization.

Along with the reorganization at the Public Hospital in Batam, the community service process was enhanced with accreditation standards. The legal basis for implementing accreditation in hospitals is Law No. 36 of
2009 concerning health, Law No. 44 of 2009 concerning hospitals and regulation of the minister of health 1144/ Minister of Health/regulations/VIII/2010 concerning the organization and work procedures of the Ministry of Health. Accreditation implies an acknowledgment given by the government to the hospital because it has met the standards set.

Based on the background, the problems in this study can be formulated as follows:

1. Is the empowerment of human resources directly influencing the quality of services of Batam City Fatimah Embung Public Hospital?

2. Does good governance have a direct effect on the quality of services in Batam's Fatimah Embung Public Hospital?

3. Do monitoring and evaluation directly affect the quality of employee service quality?

4. Is the empowerment of human resources a direct influence on monitoring and evaluation?

5. Does good governance have a direct effect on monitoring and evaluation?

6. Is the empowerment of human resources a direct influence on good governance?

\section{THEORETICAL FRAMEWORK}

\subsection{Empowerment}

Empowerment is a social and personal process to encourage strength, competence, creativity and individual freedom to act [3]. Empowerment is truly meaningful employee engagement. Empowerment is the authority to make decisions in an area of certain operating activities without having to obtain the endorsement of others [15]. [24] arguing that empowerment is a multifaceted one whose essence cannot be covered in one single concept. In other words, empowerment implies the need for freedom to individuals to act and at the same time be responsible for their actions in accordance with their duties carrying it to develop the potential and ability of human resources so that they are able to carry out the work tasks they carry out and produce meaningful work on the program that is planned jointly. This condition needs to be pursued continuously in accordance with the principles of individual empowerment in order to develop individual potential.

\subsection{Good Governance}

Governance is a management mechanism economic and social resources involving the influence of the state and non-sectors the country in a collective effort. Good governance is also intended as a managerial ability to manage the resources and affairs of a country by means of open, transparent, accountable, equitable, and responsive to community needs [28]. 
Meanwhile, [12] stated that what is meant by the implementation of a new public management program is to carry out an action that is intended to improve the efficiency and effectiveness of public services and public service organizations, by having a view or value that prioritizes accountability and improving the delivery of public services.

\subsection{Monitoring}

According to [9], supervision can be defined as a process to ensure that organizational goals in management are achieved.

Supervision as an inspection process related to position of organizational structure, workflow \& authority limits, executive interactions and management information systems are carried out for achieve the ultimate goal of an organization [19].

\subsection{Evaluation}

Evaluation can be defined as a process systematic collection of information that will later be used as new knowledge in support existing decisions.

Evaluation is a process to provide information on the extent to which a particular activity has been achieved, and how the difference in achievement with a certain standard to find out whether there is a difference between the two, and how the benefits have been compared to expectations obtained.

Monitoring and evaluation is a continuous process that includes collecting data, processes and selecting information about project implementation, progress achieved on the project to the impact and effects of the project. [20] in his research on the Role of Motivators showed that the role of monitoring was emphasized on supervision in implementation and management.

\subsection{Service Quality}

Today, the public service is not monopoly of the government, but also organized by the private sector and non-governmental organizations [8].

Service quality is fulfilment of consumer expectations or consumer needs that compare the results with expectations and determine whether consumers already received quality services [17].

If services received exceed consumer expectations, then the quality of services is perceived as ideal. Conversely if the services are received lower than expected, the quality of services considered bad [26].

The word Empowerment and Human Resources, if put together is to become "Empowerment of Human Resources", then in this context, the understanding is: a process of business activities to further empower "human power" through human change and development itself, in the form of competency confidence, authority, and responsibility in the context of implementing organizational activities to improve performance as expected in other fields and in the education sector.

[5] state that governance can be defined as the processes through which individuals and state officials interact to express their interests, exercise their rights and obligations, work-out their differences, and cooperate to produce public goods and services.

It is the same with the view of [10] which states that the term of governance refers to the concept of governance and administration are far more extensive and comprehensive than during the reign of this practice. Governance herein means the process of participation in the management of social affairs, economics and politics of a country, state or local community through the structure and value of which is a reflection of society [10].

\subsection{Conceptual Framework}

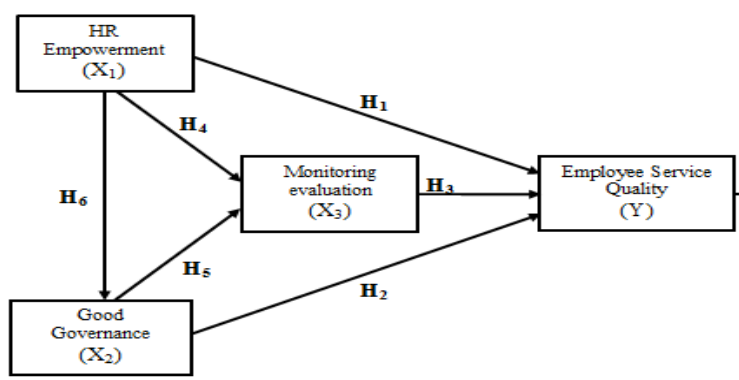

Figure 1: Conceptual Framework

Based on the problem formulation and literature review described in the previous chapter, the conceptual framework of research refers to relevant theories and previous studies. As a comprehensive picture of the interrelationship between variables used in the research model, below is presented a chart of the research conceptual framework. Where the research framework can be described in (Figure 1).

Based on the above study and the theoretical framework described above, the research hypothesis is formulated as follows: 1) HR Empowerment has a direct effect on Employee Service Quality; 2) Good governance has a direct effect on Employee Service Quality; 3) Monitoring evaluation has a direct effect on Employee Service Quality; 4) HR empowerment has a direct effect on monitoring evaluation; 5) Good governance has a direct effect on monitoring evaluation; 6) HR empowerment has a direct effect on good governance.

\section{RESEARCH METHOD}

The unit of analysis of this study was the employees of the Embung Fatimah Public Hospital with a sample of 129 respondents. The data analysis used for this study is descriptive analysis and inferential analysis. Descriptive analysis is used in terms of data presentation, central size, and size of the spread. Data presentation is a distribution list and histogram, the central size is the mean, median, and mode. The size of the spread is the variance and standard deviation. 
The inferential analysis is used to test hypotheses using path analysis which is preceded by a test for normality and homogeneity of variance. The test can calculatethe direct and indirect effects of independent variables on a dependent variable. This influence is reflected in the coefficient path.

\section{ANALYSIS}

In this study, data gathered is data from four variables, including employee service quality and monitoring and evaluation as endogenous variables. Empowerment of human resources and good governance as executive variables. The description of each research variable can be explained as follows:

a) Employee Service Quality: Based on the data obtained from 129 research respondents, after being processed statistically it shows the following results. The minimum score obtained is 87 and the maximum score is 133 from the calculated range. The next calculation gives the average value (Y) of 110.27, the middle or medium value (Me) is 111 and the mode (Mo) is 120 , the standard deviation is 11.89 and the variance is 141.39 .

b) Empowerment of Human Resources: Based on data obtained from 129 research respondents after being processed statistically, the results are as follows: the minimum score obtained is 52 and the maximum score is 103 from the calculated range. The next calculation gets the average value (X1) 76.79 middle or medium value (Me) of 77 and mode (Mo) of 60, the standard deviation of 13.91 fibre variance is 193.60.

c) Good Governance: Based on data obtained from 129 research respondents after being processed statistically showed the following results: the minimum score obtained from 92 and the maximum score is 138 from the calculated range. The next calculation gives the average value (X2) 114.53, the middle value or medium (Me) of 115 and the mode (Mo) of 113 and 120, the standard deviation is 11.73 and the variance is 137.58 .

d) Monitoring and Evaluation: Based on data obtained from 128 research respondents after being processed statistically shows the following results: The minimum score obtained is 48 and the maximum score is 94 from the calculated range. The next calculation gives the average value (X3) 74.62, the middle or medium value $(\mathrm{Me})$ is 78 and the mode (Mo) is 78, the standard deviation 12.10 and the variance is 146.30 .

e) Path Coefficient Calculation: Before calculating the path coefficient, the calculation of the coagulation coefficient between variables is performed. The calculation results show that all correlation coefficients between variables are positive. This shows that there is a positive relationship between the variables contained in the structural model. All of the correlation coefficient values are significant at $\alpha=$ 0.05 . A summary of simple correlation coefficients between research variables can be presented in the following table matrix.

Table 2. Simple Correlation Coefficient Matrix between Variables.

\begin{tabular}{|c|c|c|c|c|c|}
\hline \multirow{2}{*}{ Model } & \multicolumn{2}{|c|}{$\begin{array}{c}\text { Unstandardized } \\
\text { Coefficients }\end{array}$} & \multirow{2}{*}{ Beta } & $t$ & \multirow{2}{*}{ Sig. } \\
\cline { 2 - 6 } & B & Std Error & & & \\
\hline $\mathrm{X} 1-\mathrm{Y}$ & .366 & .071 & .429 & 5.132 & .000 \\
\hline $\mathrm{X} 2-\mathrm{Y}$ & .235 & .083 & .231 & 2.832 & .005 \\
\hline $\mathrm{X} 3-\mathrm{Y}$ & .237 & .077 & .241 & 3.066 & .003 \\
\hline $\mathrm{X} 1-\mathrm{X} 3$ & .376 & .075 & .433 & 4.994 & .000 \\
\hline $\mathrm{X} 2-\mathrm{X} 3$ & .384 & .089 & .372 & 4.296 & .000 \\
\hline $\mathrm{X} 1-\mathrm{X} 2$ & .617 & .051 & .732 & 12.119 & .000 \\
\hline
\end{tabular}

The next step is to calculate the path coefficient. To answer the objectives in this study, the main structure in the research model was broken down into three substructures. The following is the SPSS output of the three structures summarized in the table 3 .

The output results above are included in the structural equation drawings as follows:

1) Based on the calculation results show that HR empowerment has a positive and significant effect on employee service quality. This can be seen from the path coefficient py $1=0.429$. To find out whether or not the significance of HR empowerment has a direct effect on employee service quality, a significance test is carried out by t-test the significant path coefficient if the t-count $>\mathrm{t}$ table. The results of t-test calculations obtained $\mathrm{t}$-count $=$ 5.132, while t-table $=2.326$, at $\alpha=0.01$ with $\mathrm{dk}=127$, so that t-count $>\mathrm{t}-5$ ) table or 5.132> 2.326, then $\mathrm{HO}$ is rejected and $\mathrm{H} 1$ is accepted, the path coefficient py1 is very significant. Thus, HR empowerment (X1) has a positive direct effect on employee service quality (Y).

Table 3: SPSS Output Three Sub Structures

\begin{tabular}{|c|c|c|c|c|}
\hline & $X_{1}$ & $X_{2}$ & $X_{3}$ & $Y$ \\
\hline$X_{1}$ & 1,000 & & & \\
\hline$X_{2}$ & $0,732^{*}$ & 1,000 & & \\
\hline$X_{3}$ & $0,705^{*}$ & $0,689^{*}$ & 1,000 & \\
\hline$Y$ & $0,768^{*}$ & $0,711^{*}$ & $0,702^{*}$ & 1,000 \\
\hline
\end{tabular}

2) Based on the calculation results show that good governance has a positive and significant effect on employee service quality. This can be seen from the path coefficient py $2=0.231$. To find out whether the significance of good governance has a direct effect on employee service quality, a significance test is performed by $\mathrm{t}$-test the significant path coefficient if the $\mathrm{t}$-count $>\mathrm{t}$ table. The $\mathrm{t}$-test calculation results obtained $\mathrm{t}$-count $=$ 
2.832, while t-table $=2.326$, at $\alpha=0.01$ with $\mathrm{dk}=127$, so that t-count $>\mathrm{t}-6$ ) table or $2.832>2.326$, then $\mathrm{H} 0$ is rejected and $\mathrm{H} 1$ is accepted, the path coefficient of py 2 is very significant. Thus, good governance (X2) has a positive direct effect on employee service quality (Y).

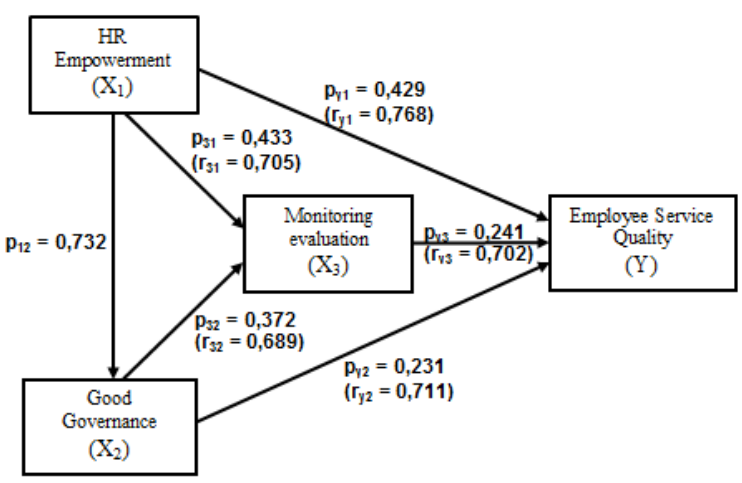

Figure 2: Path Chart

Based on the calculation results show that monitoring and evaluation have a positive and significant effect on employee service quality. This can be seen from the path coefficient py $3=0.241$. To find out the significance of monitoring and evaluation has a direct effect on employee service quality, a significance test is performed with the t-test. significant path coefficient if the value of $\mathrm{t}$-count> t-table. The results of t-test calculations obtained by $\mathrm{t}$-count $=3.066$, while $\mathrm{t}$-table $=2.326$, then $\mathrm{H} 0$ is rejected and $\mathrm{H} 1$ is accepted, the path coefficient of py3 is very significant. Thus, monitoring and evaluation (X3) has positive direct effect on employee service quality (Y).

Based on the calculation results show that the empowerment of human resources has a positive and significant effect on monitoring and evaluation. This can be seen from the path coefficient p31 $=0.433$. To find out whether the effect of empowering human resources on monitoring and evaluation is significant or not, a significance test and t-test are conducted. significant path coefficient when the value of $\mathrm{t}$-count $>\mathrm{t}$-table. The $\mathrm{t}$-test calculation results obtained $\mathrm{t}$-count $=4.994$, while $\mathrm{t}$-table $=2.326$, at $\alpha=0.01$ for $\mathrm{dk}=127$ so that $\mathrm{t}$-count $>\mathrm{t}$-table or $4.994>2.326$, then $\mathrm{H} 0$ is rejected and $\mathrm{H} 1$ is accepted, the p31 path coefficient is very significant. Thus, the empowerment of human resources (X1) has a direct positive effect on monitoring and evaluation (X3).

Based on the calculation results show that good governance has a positive and significant effect on monitoring and evaluation. This can be seen from the path coefficient p32 $=0.372$. To find out whether the significance of good governance has a direct effect on employee job satisfaction, a significance test is carried out with the t-test. significant path coefficient if the value of t-count $>\mathrm{t}$-table. The results of t-test calculations obtained t-count $=4.296$, while t-table $=2.326$ at $\alpha=0.01$ with $\mathrm{dk}=127$, so that $\mathrm{t}$-count $>\mathrm{t}$-table, or $4.296>2.326$, then $\mathrm{H} 0$ is treated and $\mathrm{H} 1$ is accepted, p32 path coefficient is very significant. Thus, good governance
(X2) has a positive direct effect on monitoring and evaluation (X3).

Based on the calculation results show that the empowerment of human resources has a positive and significant effect on good governance. This can be seen from the path coefficient $\mathrm{p} 21=0.732$. To find out whether the effect of empowering human resources on good governance is significant or not, a significance test and t-test are conducted. significant path coefficient when the value of t-count $>\mathrm{t}$-table. The results of t-test calculations are obtained $\mathrm{t}=12,119$, while $\mathrm{t}$-table $=$ 2,326 , at $\alpha=0,01$ for $\mathrm{dk}=127$ so that $\mathrm{t}$-count $>\mathrm{t}$-table or $12,119>2,326$, then $\mathrm{H} 0$ is rejected and $\mathrm{H} 1$ is accepted, p21 path coefficient is very significant. Thus, the empowerment of human resources (X1) has a positive direct effect on good governance (X2).

\section{RESULTS}

\subsection{Empowerment of Human Resources has a Positive Impact on the Quality of Employee Services}

The results of hypothesis testing indicate that the empowerment of human resources has a positive effect on employee service quality. This positive influence shows that the empowerment of high human resources will provide implications for improving the quality of employee services. Empowerment teaches employees how to make decisions and accept responsibility for work results. With empowerment, organizations will be able to obtain and retain qualified, skilled, knowledgeable and capable employees and can hire employees efficiently and efficiently. This is in accordance with the opinion of [6], [4], [11], and [21] that empowerment implies an acknowledgment that everyone has talents, competencies, and strengths that can be practiced creatively and responsibly in an organizational environment.

\subsection{Good Governance Has a Positive Impact on the Quality of Employee Services}

The results of hypothesis testing indicate that good governance has a positive effect on employee service quality. This positive influence shows that high good governance will have implications for improving employee service quality. The application of good governance is an absolute necessity of the community in order to improve a government performance that is more in favor of the interests of the people with rules that apply universally. This can also be a factor in the realization of good governance that requires that various government processes, both in terms of the process of formulating work performance levels, formulating investment flows, and implementing government policies on human resources within the government to run effectively and efficiently to improve welfare people. This is in accordance with previous research of $[2,13]$ that Good Governance Has a Positive Impact on the Quality of Employee Services 


\subsection{Monitoring and Evaluation Has a Positive Impact on Employee Service Quality}

The results of hypothesis testing indicate that monitoring and evaluation have a positive effect on employee service quality. This positive influence shows that high monitoring and evaluation will have implications for improving employee service quality. Monitoring and evaluation is one way to find out weaknesses, weaknesses, and strengths in term of planning and implementing activities / programs. Therefore, by looking at the magnitude of the interests of monitoring and evaluation, it is deemed necessary to have a guideline that is a guide or reference for all members of the organization to carry out their duties and functions in planning, monitoring and evaluating an activity. With this guideline, it is expected that the objectives and results of the implementation of monitoring and evaluation activities can be achieved properly. This is in accordance with previous research of [16] that Monitoring and Evaluation has a Positive Impact on Employee Service Quality

\subsection{Empowerment of Human Resources has a Positive Impact on Monitoring and Evaluation}

The results of hypothesis testing indicate that the empowerment of human resources has a positive effect on monitoring and evaluation. This positive influence shows that the empowerment of good human resources will have implications for improving monitoring and evaluation. This finding is understandable because empowering good human resources will result in employees working with high enthusiasm. Empowerment of human resources is done by providing the ability and opportunity for employees to develop themselves. This is clearly seen, employees who have been empowered, in fact, can improve their performance, even those who have been given the ability and opportunity to develop capabilities, are proven capable of working in accordance with their empowerment, and can improve the quality of good service. This is in accordance with previous research of [23] that Empowerment of Human Resources has a Positive Impact on Monitoring and Evaluation.

\subsection{Good Governance Has a Positive Impact on Monitoring and Evaluation}

This study shows the findings that good governance has a positive effect on monitoring and evaluation. This positive influence shows that high good governance will have implications for improving monitoring and evaluation. The implementation of good governance is a prerequisite for every government to realize the aspirations of the people and achieve the goals and aspirations of the nation-state. In this framework, it is necessary to develop and implement an appropriate, clear, measurable, and legitimate system of accountability so that governance and development can take place in an efficient, effective, clean, and responsible manner and free from corruption, collusion, and nepotism. To realize and improve the implementation of government management that is more effective, efficient, clean, accountable and results-oriented, a Government Agency Performance Accountability System is needed. The final product of the Government Agency Performance Accountability System is the performance accountability report of government agencies, which describes the performance achieved by a government agency on the implementation of programs and activities financed from the State Budget. This is in accordance with previous research of [7] that Good Governance Has a Positive Impact on Monitoring and Evaluation.

\subsection{Empowerment of Human Resources has a Positive Impact on Good Governance}

The results of hypothesis testing indicate that the empowerment of human resources has a positive effect on good governance. This positive influence shows that the empowerment of good human resources will have implications for improving good governance. This is in accordance with previous research of [14].

\section{CONCLUSIONS}

Based on the results of the research described in the previous chapter, the findings of this study can be described as follows:

a) There is a positive direct effect of empowering human resources on employee service quality. This shows that the empowerment of high human resources will result in improved service quality of employees.

b) There is a positive direct effect of good governance on employee service quality. This shows high good governance will result in an increase in the quality of employee services.

c) There is a positive direct effect of the monitoring and evaluation of employee service quality. This shows that high monitoring and evaluation will result in an increase in employee service quality.

d) There is a positive direct effect of empowering human resources on monitoring and evaluation. This shows that the empowerment of high human resources will lead to increased monitoring and evaluation.

e) There is a positive direct effect of good governance on monitoring and evaluation. This shows high good governance will lead to increased monitoring and evaluation.

f) There is a positive direct effect of empowering human resources on good governance. This shows that the empowerment of high human resources will result in an increase in good governance.

\section{REFERENCES}

[1] Aditama, Candra Yoga, Manajemen Administrasi Rumah Sakit, Jakarta, UI Bandung, 2006.

[2] Agus Nugraha, et.al., Public Service Quality in Good Governance Perspective: Study on Publishing 
Trade License in South Tangerang City. International Journal of Applied Sociology. 5(2): 2015, pp 63-75

[3] A.Pearce, John, Robinson Jr., Richard B., . Strategic Management: Formulation, Implementation, and Control. USA: Richard D. Irwin, Inc., 1994

[4] Bowen, David E. and Edward E. Lawler. Empowering service employees. Sloan Management Review. 36.4, 1995.

[5] Brinkerhoff, D, and Goldsmith, Institutional dualism and international development: a revisionist interpretation of good governance. Administration \& Society; May 2005; 37, 2; ABI/INFORM Global pg. 199.

[6] Chebat, Jean-Charles. The Impact of Empowerment on Customer Contact Employees' Roles in Service Organizations. Journal of Service Research, Volume 3, No. 1, 2009.

[7] Cloete, Fanie, Evidence-Based Policy Analysis In South Africa: Critical assessment of the emerging Government-wide Monitoring and Evaluation System. 21st IPSA World Congress of Political Science, Santiago World Congress of Political Science, Santiago, Chile, 2009.

[8] Dwiyanto, A, Public service management: attention, inclusive and collaboration, Gadjah Mada University Press, Yogyakarta, 2010.

[9] Effendi, Usman., Asas Manajemen. Cetakan Kesatu. Jakarta: PT. Raja Grafindo Persada, 2014.

[10] Farazmand, A,i (Ed), Sound governance policy and Kanisius,.administrative innovation, Praeger, Westport, Connecticut. London, 2004.

[11] Geralis, Michelle, Terziovski, Mile. A quantitative analysis of the relationship between empowerment practices and service quality outcomes. Total Quality Management \& Business Excellence, Thomas, K. W., Velthouse, B.A. 1990. Cognitive Volume 14, 2003 - Issue 1

[12] Heyer, WR, Donnelly, MA, Diarmid, RW, Hayek LC dan Foster MS. Measuring and Monitoring Biological Diversity Standard Methods for Tjiptono, F., 2005. Pemasaran Jasa. Malang: Bayumedia Amphibians. Washington:Smithsonian Institution Publishing.Pr, 1994

[13] Jarl K. Kampen, et. al. 2006. Assessing the relation between satisfaction with public service delivery and trust in government: The impact of the predisposition of citizens toward government on evaluations of its performance'.In: Public Performance and Management Review, 29 (4): 2006, pp 387-404

[14] Lillian Mwanri, et. al., Empowerment as a tool for a healthy resettlement: a case of new African settlers in South Australia. International Journal of Migration, Health and Social Care. VOL. 8 NO. 2 2012, pp. 86-97

[15] Luthans, Fred. Organizational Behavior, Eleventh edition, Mc Growth-Hill Book co, Singapore, 1998.

[16] Mulama, Kevin, et. al. Effectiveness of Monitoring and Evaluation in Enhancing Performance of Social Development Projects in Busia Country-A Survey of Government Social Development Projects. International Journal of Management Research and Reviews; Meerut Vol. 4, Iss. 8, 2014

[17] Mulyono, Manajemen Administrasi dan Organisasi Pendidikan, Yogyakarta: Ar Ruzz Media Groupm 2008.

[18] Punnakitikashem, Prattana. et.al Health Care Service Quality: Case Example of a Hospital with Lean Implementation. POMS 23 rd Annual Conference, Chicago, Illinois, U.S.A. Abstract number: 025-1232, 2012.

[19] Purwoko, Bambang. Conception of Operating Audit of National Social Security Council toward The Operational Activities of Social Security cMonitoring and Evaluation System. 21 2012.

[20] Rustandi, Yuyus.. Peran Motivator, Monitoring, dan Evaluasi Komite Sekolah dalam Meningkatkan Mutu Pendidikan di SMAN 14 Bandung. dalam Jurnal Ilmiah Pendidikan Pedagogia, 4(1)., 2011.

[21] Starratt, R.J., Menghadirkan Pemimpin Visioner: Kiat Menegaskan Peran Sekolah. Yogyakarta: Kanisius, 2007.

[22] Sugiyono, Statistika untuk Penelitian, Alfabeta, Bandung. 2012

[23] Susan B, Rifkin. A Framework Linking Community Empowerment and Health Equity: It Is a Matter of CHOICE. Journal of Health, Population and Nutrition; London Vol. 21, Iss. 3, 2003.

[24] Thomas, K. W., Velthouse, B.A. Cognitive, 1990.

[25] Elements of Empowerment: An Interpretative Model of Intrinsic Task Motivation, Academy of Management Review, Vol:15, p: 4-666.

[26] Tjiptono, F., Pemasaran Jasa. Malang: Bayumedia Publishing, 2005.

[27] Undang-undang RI No. 13 Tahun 2013 Tentang Ketenagakerjaan, 2008, Jakarta, Indonesia Legal Center Publishing.

[28] Widyananda, Herman. Revitalisasi Peran Internal Auditor Pemerintah Untuk Penegakan Good Governance di Indonesia. Publikasi, Seminar, makalah, dan Sambutan. Universitas Padjadjaran, 2008

[29] https://id.wikipedia.org/wiki/Rumah_Sakit_Umum Daerah_Embung_Fatimah 